John A. Monaco

Boston College School

School of Theology and Ministry

\title{
"Judging Shepherd of Thy Sheep": Christ and the Role of Mercy in the Dies Irae
}

One scholar considers it the "highest ornament of sacred poetry and the most precious jewel of the Latin Church." Another says: "This marvelous hymn is the acknowledged masterpiece of Latin poetry and the most sublime of all uninspired hymns." ${ }^{2}$ Admittedly, giving these impressive superlatives to the famous medieval poem, "Dies Irae" ("Day of Wrath") seems, at first, to be a bit odd. After all, the poem is often synonymous with a bleak, medieval obsession with death, judgment, and hellfire. However, for those who have discerning eyes, there is a deeper dimension, a merciful dimension, to this poem.

The $13^{\text {th }}$ century Latin hymn, Dies Irae, is one of the better-known Roman Catholic liturgical sequences, famous for its seemingly-dark portrayal of the Day of Judgment ("Day of Wrath"). Once a staple element of the Requiem Mass, this text has now been relegated to relative obscurity, finding life only in concert halls, where grandiose musical settings of the Mozart \& Verdi's "Requiem Mass" are performed. In its absence, the Dies Irae is now synonymous with a bleak, medieval theology fixated on death and judgement.

However, upon deeper examination, it seems that the "Day of Wrath" can also be read as a "Day of Mercy." Sorrow for past transgressions and preoccupation with eternal hell constitute only one element of the hymn. Far from being focused on sin and death, the Dies Irae also

\footnotetext{
${ }^{1}$ Adrian Fortescue, The Mass: A Study of Roman Liturgy (United States: Createspace Independent Publishing Company, 2015), 273.

2 Henry, H. Dies Iræ. In The Catholic Encyclopedia. New York: Robert Appleton Company, 1908. Retrieved January 27, 2017 from New Advent:

http://www.newadvent.org/cathen/04787a.htm
} 
establishes the vital connection between Christ's mercy for sinners and the mercy each Christian is called to share with one another. This is seen through the numerous Scriptural allusions which fill the hymn, including those referencing that 'final day,' when Christ is said to "judge the living and the dead." In pleading to be on the right side during the separation between the metaphorical "sheep and goats," the author acknowledges the significance of Christ and His command to love the "least of these" on the Day of Judgement (Matthew 25:40). The Dies Irae contains both a call for mercy and a call to mercy, the latter of which distinguishes itself as the litmus test of salvation.

As a preliminary note, the following are examples of what this paper is not intended to do. First, this paper will not seek to compare several translations of this poem, nor will this paper be a thorough, close reading of the text. This paper will not be an exhaustive examination of the numerous Scriptural allusions which are sprinkled throughout the text. Instead, the purpose of this paper is simply to demonstrate that the "Dies Irae" contains a twofold message: the poem represents both a call to Christ pleading for mercy, as well as a call from Christ to show mercy. Helpful to this thesis is an exegesis of Matthew 25:31-46 and other "judgment" parables in Matthew's Gospel, along with a few eschatological reflections of both Pope Emeritus Benedict XVI and Pope Francis on the "Four Last Things." For the purpose of this investigation, I will use for reference both the Latin text as published in the 1962 Roman Missal, ${ }^{3}$ as well as Daniel R. Santos' recent English (formal-equivalence) English translation. ${ }^{4}$

\footnotetext{
${ }^{3}$ Missale Romanum, Canada, and Angelus Press, The Roman Catholic Daily Missal, 1962: With Kyriale in Gregorian Notation (Kansas City, MO: Angelus Press, 2004).

${ }^{4}$ Anonymous, Dies Irae, trans. Daniel R. Santos (personal correspondence, 2017).
} 


\section{Historical Context}

Authorship of the "Dies Irae" is traditionally attributed to the $13^{\text {th }}$ century Franciscan friar, Thomas of Celano, who served as biographer to St. Francis of Assisi, but other medieval figures have been raised by historians as possible alternatives. ${ }^{5}$ Nonetheless, the composer of this text was well-versed in both Scripture and the popular, medieval Catholic understanding of the "Four Last Things" - that is, death, judgment, heaven, and hell. As the British historian James Palmer points out, "eternal punishment was a powerful corrective threat," and despite any difficulties in living an "unambiguously pure" life, the most efficient strategy for a pastoral perspective in urging the people of God to 'do better' would be to warn them 'of the terrors of Judgement in order to drive them to penitence."

What, then, of the text and its composition? Have there been any major changes to it since the $13^{\text {th }}$ century? It might be appropriate here to note that scholars typically hold that the last two lines ("Lacrimosa" and "Pie Jesu") seemed to be added at a later time, given their abrupt change in poetic structure and meter. It would make sense that these were added for a liturgical purpose, to fit the theme of the Requiem Mass as a time of mourning and offering of prayers for the deceased so that he or she would obtain God's pardon and mercy for any sins committed during this life.

Historically-speaking, if authorship can be traced to Thomas of Celano, then the writing of this poem occurred somewhere in between the emergence of the "Black Death" and violent

\footnotetext{
${ }^{5}$ Fortescue, 274.

${ }^{6}$ James Palmer, The Apocalypse in the Early Middle Ages (Cambridge, United Kingdom: Cambridge University Press, 2014), 51.
} 
rebellion within Celano's territory, the Kingdom of Naples. ${ }^{7}$ Given the historical context and the reality of death stalking the land, the theme of judgment weighed heavily on the minds of medieval, European Christians, and thus finds a prominent place in the text of the "Dies Irae."

Theologically speaking, traditional Catholic teaching, as outlined in the Catechism of the Catholic Church, holds that every person living in the "End Times" faces two "judgments" — the first being the "particular judgment," where a person's soul is judged immediately following death, as well as the "final judgment," whereby all of humanity, the souls of the deceased being reunited with their bodies, is placed before the judgment seat of Christ. With this historical and theological framework in mind, we can now proceed to the text of the Dies Irae itself.

\section{Textual Analysis}

The text can be divided into two main parts: out of the 18 stanzas, there are those which are directed towards the audience (stanzas $1-7$ ) and those stanzas which are directed to Christ (stanzas $8-17$ ). The $18^{\text {th }}$ and final stanza can be split in half, the first half being directed to the audience, and then the second half to Christ. The first seven stanzas describe of what the "Day of Wrath" will consist. "That day," as it is referred to in the first stanza, will be the time where Christ will judge the nations and the entire people — those living and those deceased. The speaker paints the scenery for "that day"- a world turned into "glowing ashes," tremors and the sound of a trumpet blaring, tombs opening, the rising of the dead, the Book of Life, and the throne of judgment. These images borrow heavily from New Testament apocalyptic literature, including that of Paul's First Letter to the Corinthians (1 Cor 15:52), as well as the Book of Revelation (Rev 20:12).

\footnotetext{
${ }^{7}$ Pietro Colletta, The History of the Kingdom of Naples: From the Accession of Charles of Bourbon to the Death of Ferdinand I (United Kingdom: I.B.Tauris, 2009), 182.
} 
It is clear that this judgment the author speaks of is the Last Judgment, given its description of the trumpet (an obvious illusion to "The trumpet shall sound" line found in 1 Cor 15:32) bringing forth human persons to the throne of judgment, their resurrected bodies united with their respective souls. Here, one can wince along with the speaker at this vivid imagery of the Last Day. Once he or she is faced with this scenery of final judgment, the speaker then shifts from addressing the audience to then addressing Christ, the Judge, as seen in stanzas $8-17$.

Acknowledging His kingship, the speaker first pleas to be "saved" (stanza 8), and then in stanza 9 craftily employs a technique of anamnesis — that is, a 'remembering' — and does so to remind Christ of His purposeful mission to humankind. This mission, of course, is salvation not obliteration (John 3:16), and the speaker politely requests not to be "cast away on that day." In the next stanza, Christ's own Passion and Death are invoked as those saving mysteries by which humankind is redeemed. Stanzas $11-16$ then become crucial for understanding the speaker's situation which is brought before Christ. Acknowledging Christ as the "just judge," the speaker asks for the "gift of pardon," for he or she groans "like one condemned," and one's "face blushes for [one's'] sins." In the thirteenth stanza, the speaker utilizes anamnesis once more, by recalling the forgiveness granted to Mary Magdalen ${ }^{8}$ and the "good thief" (Luke 23: 39-43), which then gives the speaker hope for his own possible pardon. After pleading to avoid burning "in the everlasting flame," the speaker requests "a place among the sheep," which is separate "from the goats." This is an obvious allusion to Matthew 25:31-46, where Christ divides the saved from the damned, with the sheep on the "right" side of judgment (and the Judger) and the goats on the left, where they will face "eternal punishment." The remaining stanzas include an affirmation of what is popularly called "final perseverance" (that is, the preserving of one's soul from the state of

\footnotetext{
${ }^{8}$ Popular medieval Catholic interpretations of the woman caught in adultery in John 8:1-11 held that it was Mary Magdalene, but modern scholarship has largely refuted that claim.
} 
mortal sin at the time of death), and then the text concludes with the added eighteenth stanza, which contains lacrimosa ("weeping") and finally, a prayer for mercy and eternal rest ("Pie Jesu Domine, dona eis requiem").

The first claim of this thesis (that the Dies Irae contains a plea for mercy) is quite explicit within these lines. But amidst the hellfire, where exactly is the second (and more implicit) claim of this thesis, namely, that within the text there is a call to mercy?

\section{The role of Christ as Shepherd and Judge}

On that "day of wrath," it is clear where the speaker is - trembling in fear. However, more importantly, where is Christ? Scripture is clear about the role of Christ during the Last Judgment, in fact, Christ Himself affirms it. In Matthew 25:31-46, the famous "Judgment of the Nations" passage, it is evident that the sentence of judgment is passed by none other than the “Son of Man." Elsewhere, Jesus reveals his role as judge in Matthew's Gospel during the Sermon on the Mount, where he says:

"On that day many will say to me: Lord, Lord, did we not prophesy in your name, and cast out demons in your name, and do many mighty works in your name? And then I will declare to them: I never knew you; depart from me, you evildoers (Mt. 7, 22-23).

Furthermore, in the eighteenth chapter of the Gospel of Matthew, Jesus warned that the person who is unwilling to forgive will find himself beyond the reach of God's forgiveness (cf. Matthew $18: 21-35)^{9}$

Therefore, it is evident that Christ's role on the "Day of Wrath" as "judge" is supported by Scripture. The Dies Irae, too, refers to Christ explicitly as "judge" four times and as "king"

\footnotetext{
${ }^{9}$ Stephen H Travis, I Believe in the Second Coming of Jesus (Grand Rapids: William B. Eerdmans Publishing Company, 1987), 192.
} 
once. On what, then, is Christ basing His judgment? The answer, as we have seen through his words, is "mercy." In the Gospels, Jesus judges human beings on how they show mercy and he thus rules as a king of mercy. The role of mercy in the Dies Irae is in some ways obvious, but in other ways hidden. Indeed, there are pleas for mercy found throughout the second half of the poem. To say that these pleas come from a place of guilt and acknowledgment of one's sins would not be incorrect; however, to say so would be to argue from only one angle. In the popular Catholic imagination, we encounter confessionals, penances, and the famous expression, "Catholic guilt." But what are the sins committed that warrant eternal damnation, and moreover, how is one to be judged at the end of one's life and the end of life itself? Is sin merely the breaking of arbitrary rules, or is there something more to the Last Judgment? Here, the second angle and presence of "mercy" emerges. The Christian, at the end of life, will be judged based on how he or she showed mercy to others, especially the most vulnerable and marginalized. Nowhere is this clearer in the Gospels than in the aforementioned "Judgment of the Nations" scene in Matthew 25:31-46, where Jesus divides the sheep and the goats - those who showed mercy "to the least of these" and those who did not. Christ explicitly includes in his exposition of judgment a scathing critique of those who ignore the poor, the hungry, the thirsty, the naked, and the imprisoned. We see also in the parable of the rich man and Lazarus (Luke 16:19-31) that lack of care for the poor was also grounds for condemnation. ${ }^{10}$ Christ's strong warning in Matthew 25:31-46 is the basis of the Catholic "corporal works of mercy." St. Augustine of Hippo powerfully encapsulates Christ's teaching on judgment based on the call to mercy in one of his sermons, where he imaginatively puts the following words into the mouth of Christ:

“...he will turn towards those at his left hand: . . . "I placed my poor little ones on earth for you. I as their head was seated in heaven at the right hand of my Father - but on earth

${ }^{10}$ Travis, 191. 
my members were suffering, my members on earth were in need. If you gave anything to my members, what you gave would reach their Head. Would that you had known that my little ones were in need when I placed them on earth for you and appointed them your stewards to bring your good works into my treasury. But you have placed nothing in their hands; therefore you have found nothing in my presence." 11

Similarly, Pope Emeritus Benedict XVI, in his encyclical Deus Caritas Est, calls to mind how, in the parable of the Judgment of the Nations, it is revealed that the "love of God and love of neighbor have become one: in the least of the brethren we find Jesus himself, and in Jesus we find God."12

More recently, Pope Francis, in one of his first general audiences as pope, had this to say about the Final Judgment:

"Dear brothers and sisters, may looking at the Last Judgement never frighten us: rather, may it impel us to live the present better. God offers us this time with mercy and patience so that we may learn every day to recognize him in the poor and in the lowly. Let us strive for goodness and be watchful in prayer and in love." 13

Later that year, Pope Francis returned to this theme in a homily, saying: "When Judgment Day comes we will look at the Lord (and say), 'Lord I have many sins, but I tried to be faithful.' "14

\footnotetext{
${ }^{11}$ St. Augustine, Sermo 18, 4: PL 38, 130-131

12 Benedict XVI, God is Love, Deus caritas est, (25 December, 2005), §15, The Holy See, http://w2.vatican.va/content/benedict-Xvi/en/encyclicals/documents/hf_benxvi_enc_20051225_deus-caritas-est.html

${ }^{13}$ Francis, General Audience on the "Final Judgment", (24, April 2013), https:/w2.vatican.va/content/francesco/en/audiences/2013/documents/papafrancesco_20130424_udienza-generale.html

14 "Threat of Hell Is Real for Not Being Faithful to God, Pope Says," Catholic News, November 22, 2016, accessed January 27, 2017, http:/www.catholicnews.com/services/englishnews/2016/threat-of-hell-is-real-for-not-beingfaithful-to-god-pope-says.cfm.
} 
Lastly, Francis remarked in February 2015 that "For Jesus, what matters above all is reaching out to save those far off, healing the wounds of the sick, restoring everyone to God's family.",15

\section{Conclusion}

Thus, by asking what the role of Christ and mercy is within this poem, we can now arrive at the logical conclusion. If the Dies Irae follows the speaker, who, on the Day of Judgment is pleading for mercy over past sins and transgressions, and we understand that on that final day we will be judged by how we showed mercy, then it follows that the famous "Day of Wrath" liturgical poem is not only about a calling for mercy, but also a calling to mercy. Here, Christ is both the Shepherd who leads us by example to the exemplary moral life, and the Judge who examines the inmost depths of our hearts. It is Christ Himself who reveals that "...the works of mercy performed are ultimately an expression of how the righteous embrace the gospel.",16 Therefore, in regards to "that day," the "Day of Wrath," we can allow the wise words of St. John of the Cross to serve as our litmus test for salvation: "in the evening of life, we will be judged on love." $" 17$

15 "Pope Francis to Church: Don't Be a Closed Caste or Afraid of Outcasts," Religious News Service, February 15, 2015, accessed January 27, 2017, http://religionnews.com/2015/02/15/pope-francis-preaches-gospel-marginalized-calls-openwelcoming-church/.

${ }^{16}$ Robert N Wilkin et al., Four Views on the Role of Works at the Final Judgment (Grand Rapids, MI, United States: Zondervan, 2013), 169.

${ }^{17}$ St. John of the Cross, Dichos 64. 
Bibliography

Colletta, Pietro. The History of the Kingdom of Naples: From the Accession of Charles of Bourbon to the Death of Ferdinand I. United Kingdom: I.B.Tauris, 2009.

Fortescue, Adrian. The Mass: A Study of Roman Liturgy. United States: Createspace Independent Publishing Company, 2015.

Gibson, David and More. "Pope Francis to Church: Don't Be a Closed Caste or Afraid of Outcasts.” February 15, 2015. Accessed January 27, 2017.

http://religionnews.com/2015/02/15/pope-francis-preaches-gospel-marginalized-callsopen-welcoming-church/.

Glatz, Carol. "Threat of Hell Is Real for Not Being Faithful to God, Pope Says." November 22, 2016. Accessed January 27, 2017. http://www.catholicnews.com/services/englishnews/2016/threat-of-hell-is-real-for-notbeing-faithful-to-god-pope-says.cfm.

Palmer, James. The Apocalypse in the Early Middle Ages. Cambridge, United Kingdom: Cambridge University Press, 2014.

Roman Catholic Church. The Daily Missal and Liturgical Manual, with Vespers for Sundays and Feasts: From the Editio Typica of the Roman Missal and Breviary, 1962: With Supplements Containing the Additional Masses for England and Wales, Scotland and the United States. 2nd ed. London: Baronius Press, 2005.

Romanum, Missale, Canada, and Angelus Press. The Roman Catholic Daily Missal, 1962: With Kyriale in Gregorian Notation. Kansas City, MO: Angelus Press, 2004.

Travis, Stephen H. I Believe in the Second Coming of Jesus. Grand Rapids: William B. Eerdmans Publishing Company, 1987.

Wilkin, Robert N, Thomas R Schreiner, James D G Dunn, Michael P Barber, Alan P. Stanley, and Stanley N Gundry. Four Views on the Role of Works at the Final Judgment. Grand Rapids, MI, United States: Zondervan, 2013. 